\title{
Origin of Dissolve Ions in Groundwaters in the Northern Densu River Basin of Ghana Using Stable Isotopes of ${ }^{18} \mathrm{O}$ and ${ }^{2} \mathrm{H}$
}

\author{
Abass Gibrilla $^{1,2}$, Shiloh Osae ${ }^{1,2}$, Tetteh. T. Akiti ${ }^{2}$, Dickson Adomako ${ }^{3}$, Samuel .Y. Ganyaglo ${ }^{1}$, \\ Edward. P. K. Bam ${ }^{1,2}$, Alhassan Hadisu ${ }^{4}$ \\ ${ }^{1}$ Department of Chemistry, National Nuclear Research Institute, GAEC, Legon, Ghana \\ ${ }^{2}$ Graduate School of Nuclear and Allied Sciences, Legon, Ghana \\ ${ }^{3}$ Department of Physics, National Nuclear Research Institute, GAEC, Legon, Ghana \\ ${ }^{4}$ AVRL Accra West, Weija Water Treatment Plant, Accra, Ghana \\ E-mail: gibrilla2abass@yahoo.co.uk \\ Received October 12, 2010; revised November 15, 2010; accepted December 17, 2010
}

\begin{abstract}
Stable isotopes of oxygen-18 and deuterium content in groundwater, surface water and rainfall in the northern part of the Densu river basin were studied with the main aim of identifying the origin and sources of ions in the groundwater in the area. The conversion of stable isotopes to d-excess was also exploited as a complementary tool to understand the processes of recharge. A comparison of the isotopic data with the rainfall, Local Meteoric Water Line (LMWL) and Global Meteoric Water Line (GMWL) indicates that the groundwater in the study area is mainly meteoric with few groundwater and all the surface water showing an evidence of evaporation. The study has also shown that, mineral dissolution from the geology is the main factor controlling the chemistry of the groundwater with evaporation having a minimal effect. The d-excess values show that the groundwater has undergone dilution with the rainfall and this is observed from the decrease of the d-excess of the groundwater with increase in Oxygen-18. This observation also suggests a modern day recharge to the groundwater.
\end{abstract}

Keywords: Dissolution, D-Excess, Meteoric, Primary Evaporation, Densu River

\section{Introduction}

Water isotope hydrology addresses the application of the isotopes that form water molecules. These are the oxygen $\left({ }^{16} \mathrm{O},{ }^{17} \mathrm{O},{ }^{18} \mathrm{O}\right)$ and the hydrogen isotopes $\left({ }^{1} \mathrm{H},{ }^{2} \mathrm{H},{ }^{3} \mathrm{H}\right)$. These isotopes (unlike other tracers of 'water' such as $\mathrm{Cl}^{-}$ which are still widely used) are ideal tracers of water sources and movement because they are constituents of the water molecules [1].

These Elements (hydrogen, oxygen) undergo changes in the various phases of hydrologic environments-atmosphere, hydrosphere, biosphere and the upper part of the earth's crust. These changes results in isotopic fractionation to give isotopic "fingerprints" due to different physicochemical, biochemical, kinetic and thermodynamic effects [2].

The isotopic fractionation at any location are affected by the geology of the area, origin of the water, climate (evaporation, condensation, melting) and other local effects(simple mixing at or below the surface) [3].

In low temperature systems, however, hydrogen and oxygen isotopes behave conservatively in the sense that as they move through a catchment; any interactions with oxygen and hydrogen in the organic and geologic materials in the catchment will have a negligible effect on the ratios of isotopes in the water molecule.

The correlation between $\delta^{2} \mathrm{H}$ and $\delta^{18} \mathrm{O}$ in atmospheric precipitation commonly called Global meteoric water line [4] is defined by the expression

$$
\partial^{2} \mathrm{H}=8 \partial^{18} \mathrm{O}+10
$$

Because of differences in meteorological conditions such as evaporation in precipitation source areas, the fractionation of oxygen and hydrogen does not normally occur under equilibrium conditions so there is a difference between $\delta^{2} \mathrm{H}$ and $\delta^{18} \mathrm{O}$. This parameter was defined 
as d-excess [5], it is both an indicator of non-equilibrium process and an index of evaporation rate formulated as

$$
\text { dexcess }=\partial^{2} \mathrm{H}-8 \partial^{18} \mathrm{O}
$$

The d-excess in precipitation depends mainly on meteorological conditions such as relative humidity, temperature and wind regime in the precipitation source area [6]. Lower relative humidity cause higher d-excess values in precipitation and vice versa.

Other authors also showed that d-excess values are partly related to mixing of evapotranspiration waters vapor fluxes from continental surfaces occurring along storm cracks [7] and re-evaporation of raindrops below the cloud base [8].

For this reason, the d-excess has been used as a diagnostic tool to interpret the contribution of water vapour from different sources to the atmosphere at a given location.

Environmental isotopes investigation of groundwater bodies has, therefore, become an important tool in water resources and management. This is because, it also allows conclusion to be drawn as regards the recharge process, the location of recharge and discharge areas, aquifer continuity, sources of ions in water and turnover time $[9,10]$.

Earlier work in Ghana on environmental isotope hydrology is attributed to Akiti [1]. Several other authors such as [11-14] later used environmental isotopes such as oxygen-18 $\left(\delta^{18} \mathrm{O}\right)$ and hydrogen $\left(\delta^{2} \mathrm{H}\right)$ in groundwater resources evaluation mostly as complementary analytical tool to conventional hydrological and hydrochemical assessment procedures.

In this paper, an attempt has been made using stable isotopes ratio of ${ }^{2} \mathrm{H} /{ }^{1} \mathrm{H}$ and ${ }^{18} \mathrm{O} /{ }^{16} \mathrm{O}$ to investigate the origin of the groundwater in the study area. Also investigated are the possible sources of ions in the groundwater and surface waters. Finally in this study, we aim at using d-excess data to identify the influence of moisture sources and local hydrologic cycle on rainfall.

\section{Materials and Methods}

\subsection{Study Area and Climate}

The Densu River Basin is a coastal river basin and covers a total area of about $2564 \mathrm{~km}^{2}$. It lies between latitude $5^{0} 30^{\prime} \mathrm{N}$ and $6^{0} 20^{\prime} \mathrm{N}$ and longitudes $0^{0} 10^{\prime} \mathrm{W}$ to $0^{0} 35^{\prime} \mathrm{W}$ Figure 1. It has a typical rain forest zone at north-west of Koforidua. The River takes its source from the Atewa Range of hills near Kibi in the Eastern Region of Ghana. The river shares its catchments boundary with the Odaw and Volta basins to the east and north respectively, the Birim basin in the northwest and the Ayensu and Okrudu in the west. The main tributaries include rivers Adeiso, Nsakyi, Dobro and Kuia [15]. The river covers a total distance of about $116 \mathrm{~km}$ from the source to the point where it enters the sea (Gulf of Guinea) through a small delta (Sakumo tidal lagoon) at Botianor, west of Accra.

The climate the study area lies in the wet semi equatorial climatic zone, characterized by two rainfall maxima (May to June and September to October), followed by a prolonged dry season.

The mean annual rainfall recorded for 10 years during the period 1993 to 2003 obtained from the Ghana Meteorological Agency (GMA) varies from $1206 \mathrm{~mm}$ at Nsawam to $1487 \mathrm{~mm}$ at Kibi.

Maximum and Minimum monthly temperature and normal rainfall distributions are shown in Figure 2 and Figure 3 respectively.

Relative humidity in the study area varies from 41 to 93\% Figure 4.

\subsection{Geology and Groundwater Occurrence}

The basin is underlain mainly by the Proterozoic basin-type granitoid (called Cape Coast batholiths), granite with associate gneiss which covers about $90 \%$ of the area (Figure 1). It is composed of quartz, muscovite, schists gneisses, orthoclase and albite. These gneissic rocks are intruded by both acidic and basic igneous rocks (white and pink pegmatite, aplites, granodiorite and dykes).

The other formations are the Birimian formation, which occurs at the watershed of the river in the northwest and consist of sandstones, tuffs, grit, quartzites and some breccia. The Togo formation underlies the southeastern portion and the area south of Weija to the estuary portion of the basin.

The cape coast granitoid have very little intergranular pore-space and are thus characterised by little or negligible primary porosity and permeability. The groundwater flow therefore, occurs in secondarily formed structures, mostly fractures, joinings, shearings, and deep weathering in the rocks $[16,17]$. The secondary porosity and flow guiding structures are mainly as a result of tectonic processes such as folding, mineral orientation (foliation), fracturing and faults (displacement along fractures), shrinking during cooling of rock mass and weathering $[16,18]$. This gives rise to two distinct types of aquifers in the basin, i.e., the fractured zone aquifer and the weathered zone aquifers.

The fractured zone aquifers develop in the bedrock at depth of about $20 \mathrm{~m}$ or more below ground surface, they tend to be localized in nature and groundwater occurrences are controlled by degree of fracturing and the 


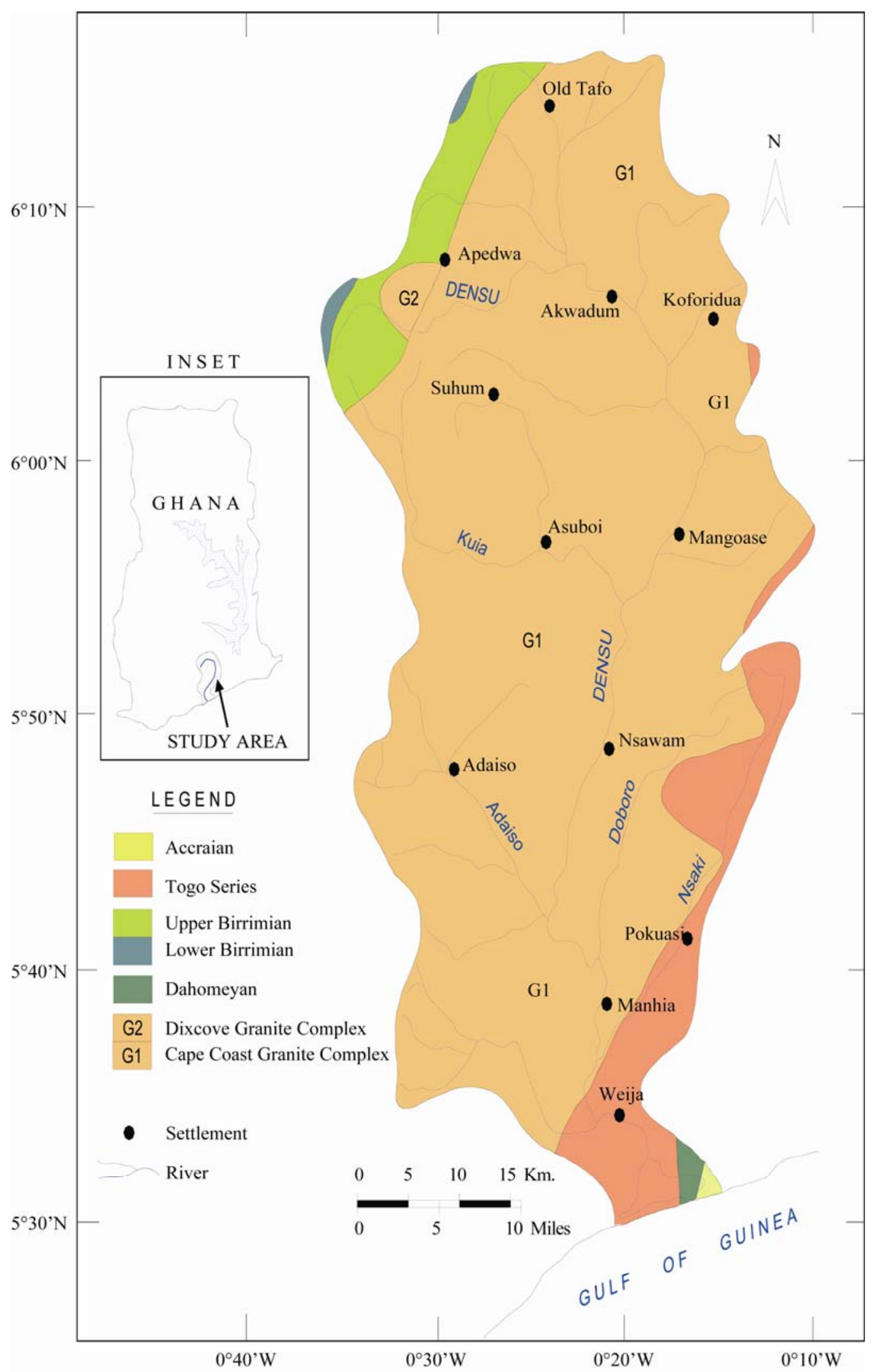

Figure 1. Geological map of the study area. 
nature of groundwater recharge. Borehole yields within the fractured zone are determined by the extent and degree of fracturing [19]. Transmisivity varies between 1 and $72 \mathrm{~m}^{2} /$ day.

The thickness zone varies greatly depending on the

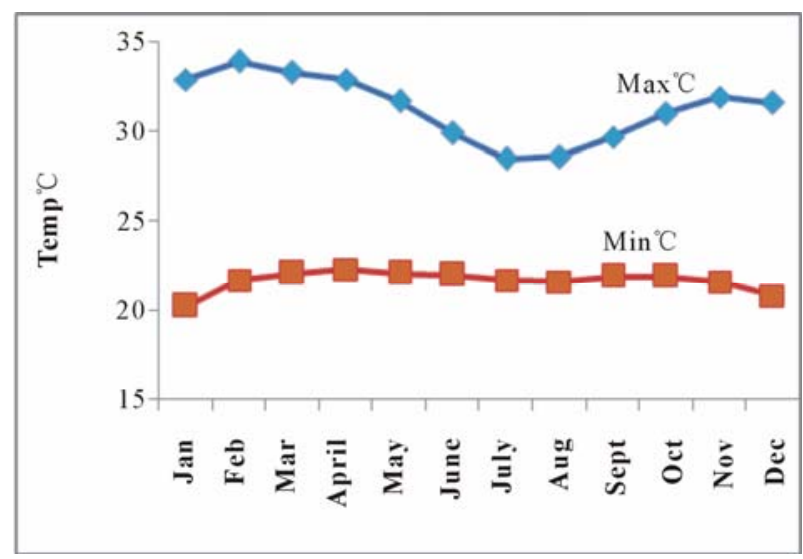

Figure 2. Monthly mean temperature distribution at koforidua.

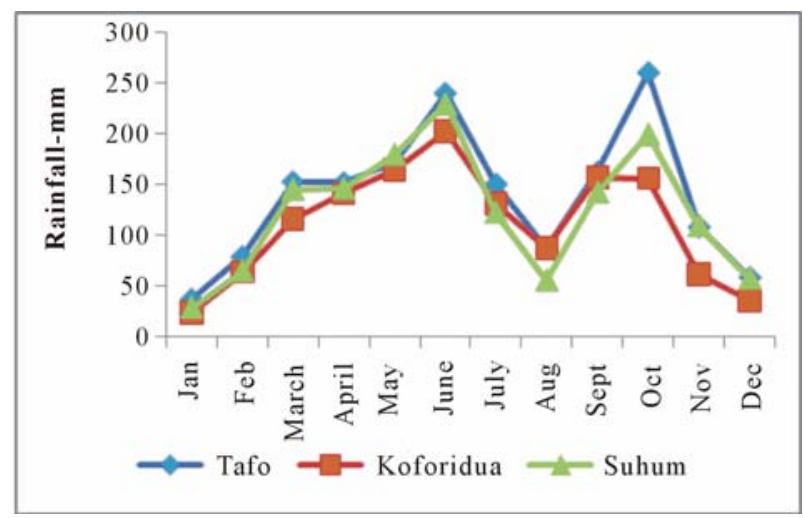

Figure 3. Monthly mean rainfall (mm) at tafo (1939-1975), koforidua (1965-1998) and suhum (1947-1971).

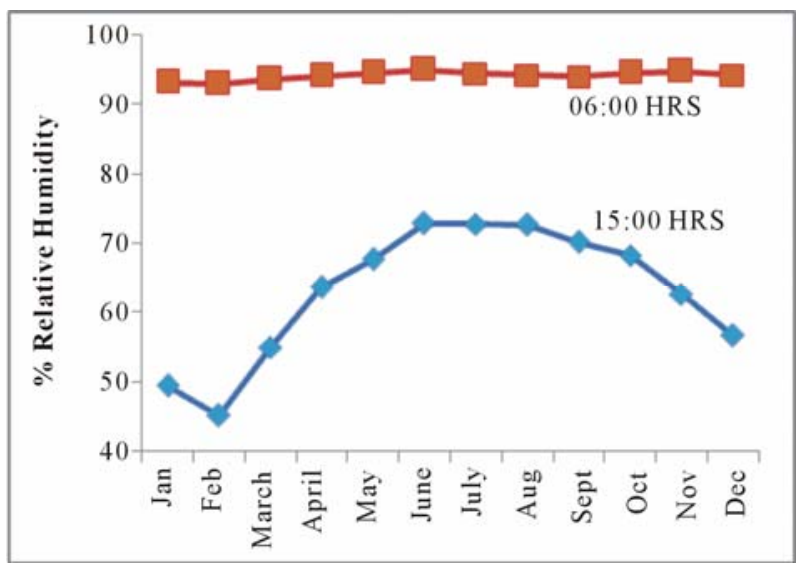

Figure 4. Monthly \% relative humidity at doforidua tafo and suhum. conditions of the rocks and ranges between 4 to $20 \mathrm{~m}$ as a unit [20]. In most communities, the weathered zone aquifer is developed for water supply by hand dug wells [21]. But most of these wells dry up during the dry season. The thick weathered zones occur in the forested area in the basin. A formation which combines the thick weathered zone with well fractured bedrock provides the most productive aquifers.

The Birimian formation to the northwestern portion of the basin are generally well folded and deeply weathered, hence groundwater occurrence in this formation is very high. The granites in the basin are less fractured and weathered, hence groundwater occurrence are moderately low. The granitic aquifers thus formed are usually phreatic to semi-confined in character, structurally dependent and often discontinuous in occurrence [19,20]. However, in the northern portion of the granitic formation relatively high productive wells exist.

The thickness of the mean weathered zone ranges from 1.0 and $32.0 \mathrm{~m}, 5.0$ and $27.0 \mathrm{~m}$ in the granites and Birimian respectively. The depth of the borehole varies from 9.1 to $103.0 \mathrm{~m}$ in the granites and 23.0 to $40.0 \mathrm{~m}$ in the Birimian [21].

Borehole yields are highly variable and lie in the range of $0.1-30.0 \mathrm{~m}^{3} \mathrm{~h}^{-1}$ with mean value of $2.0 \mathrm{~m}^{3} \mathrm{~h}^{-1}$ in the granite, and $0.7-9.0 \mathrm{~m}^{3} \mathrm{~h}^{-1}$ with the mean value $3.7 \mathrm{~m}^{3} \mathrm{~h}^{-1}$ in the Birimian [21].

However, borehole yields vary from location to location and the chemistry of the groundwater also varies from well to well. The general direction of groundwater is estimated to be from the northern portion towards the southern portion of the basin [1].

During the wet seasons, the water table generally gets higher supplying water to a number of shallow wells. This also permits the movement of fresh recharge water beyond the weathered zone into the fractured aquifer, particularly in places where there is hydraulic continuity between the weathered zone and the underlying fractures or fissures [19].

\subsection{Field Work}

A total of twenty two samples comprising of 13 boreholes and hand-dug well and 4 surface water (River Densu) and 5 rainfall events were sampled at various locations. In Figure 1, all the water samples were collected in $500 \mathrm{ml}$ pre conditioned high density polyethylene bottles. They were conditioned by washing initially with five $(5 \%)$ percent nitric acid, and then rinsing several times with distilled water. This was carried out to ensure that the samples bottles were free from contaminants. The borehole were purge of stagnant water followed by in situ measurement of Electrical conductivity 
(EC), Total dissolve solids (TDS) and $\mathrm{pH}$ were done using Hach potable EC and $\mathrm{pH}$ meters. Samples for isotopes analysis were collected in $60 \mathrm{ml}$ glass bottle filled to the brim and securely capped.

\subsection{Laboratory Analysis}

Analysis of chloride $\left(\mathrm{Cl}^{-}\right)$and Nitrate $\left(\mathrm{NO}_{3}{ }^{-}\right)$were done at the isotope hydrology lab, Department of Chemistry, National Nuclear Research institute, GAEC using a Dionex ICS 90 ion chromatograph equipped with an AS14A-5 $\mu \mathrm{m}$ ion pac column. The stable isotope analysis of the samples was carried out at HMGU, Institute of Groundwater Ecology (Neuherberg/Germany) using Isotope mass spectrometry.

The variation in isotope ratio $\mathrm{D} / \mathrm{H}$ and ${ }^{18} \mathrm{O} /{ }^{16} \mathrm{O}$ in water samples are expressed in terms of per mille deviation (\%o) relative to internal standards that were calibrated using the Vienna-Standard Mean Ocean Water (VSMOW). The data was then normalized following Coplen (1988) as follows

$$
\delta \% \text { o }\left[\frac{\mathrm{R}_{\text {sample }}}{\mathrm{R}_{\text {V-SMOW }}}-1\right] * 1000
$$

where

$\mathrm{R}_{\text {sample }}$ represent either the ${ }^{18} \mathrm{O} /{ }^{16} \mathrm{O}$ or the $\mathrm{D} / \mathrm{H}$ ratio of the samples.

$\mathrm{R}_{\mathrm{V} \text {-SMOw }}$ represents either the ${ }^{18} \mathrm{O} /{ }^{16} \mathrm{O}$ or the $\mathrm{D} / \mathrm{H}$ ratio of the $\mathrm{V}$-SMOW. The analytical reproducibility was $0.1 \%$ for oxygen and $1 \%$ o for deuterium.

\section{Results and Discussions}

\subsection{Environmental Isotopes Deuterium $\left(\delta^{2} H\right)$ and Oxygen-18 $\left(\delta^{18} \mathrm{O}\right)$}

The Statistical summary of the result of $\delta^{18} \mathrm{O}$ and $\delta^{2} \mathrm{H}$ in groundwater, surface water and rain in the study area are presented in Table 1, while the physico-chemical and isotopic data were presented in Table 2 and Table 3 respectively.

Deuterium values of thirteen (13) groundwater ranges from -9.4 to $-4.6 \%$ while oxygen- 18 values range from
-2.72 to $-1.62 \%$ VSMOW. The average values of $\delta^{2} \mathrm{H}$ and $\delta{ }^{18} \mathrm{O}$ were $-7.35 \pm 1.62 \%$ and $-2.28 \pm 0.37 \%$ respectively. The best fit regression line of the groundwater was $\partial^{2} \mathrm{H}=4.13 \partial^{18} \mathrm{O}+2.04$ with a correlation coefficient of $\mathrm{r}^{2}=0.899$. The surface water had $\delta^{2} \mathrm{H}$ and $\delta{ }^{18} \mathrm{O}$ ranging from -5.58 to $-4.40 \%$ and -1.68 to $-1.51 \%$ respectively with an average of $-5.10 \pm 1.64$ for $\delta^{2} \mathrm{H}$ and $-1.60 \pm 0.09$ for $\delta^{18} \mathrm{O}$. The best fit regression line was $\partial^{2} H=6.34 \partial^{18} \mathrm{O}+5.03$ with a correlation coefficient of $\mathrm{r}^{2}=0.945$. The Rainfall samples also had $\delta^{2} \mathrm{H}$ ranging from 10.64 to $7.35 \%$ and $\delta^{18} \mathrm{O}$ from -3.14 to $-0.71 \%$ with an average of $0.31 \pm 7.48$ and $-1.58 \pm 0.99$ for $\delta^{2} \mathrm{H}$ and $\delta{ }^{18} \mathrm{O}$ respectively. These rainfall samples were defined by the best fit regression line of $\partial^{2} \mathrm{H}=7.46 \partial^{18} \mathrm{O}$ +12.16 with a correlation coefficient of $r^{2}=0.984$.

The spatial distribution of $\delta^{18} \mathrm{O}$ and $\delta^{2} \mathrm{H}$ values of surface water and groundwater showed an obvious tendency for the average of $\delta^{18} \mathrm{O}$ and $\delta^{2} \mathrm{H}$ to increase from surface water to groundwater. Both groundwater and surface water shows shifting samples towards heavier values, this is a typical phenomenon prior to recharge in semiarid areas. It was observed that both the groundwater and the surface water have slopes lower than the rainfall. The lower slope implies primary evaporation during precipitation as the moisture moves allowing time for more contact and exchange with the atmosphere. The observed isotopic variation in the rainfall might be due to different rainfall events. The slope of 7.46 and intercept of 12.16 in the rainfall is comparable to the slope of 7.86 and intercept of 13.16 obtained by Akiti, indicating similar moisture sources and hydrological cycle for the rainfall.

\subsection{Origin of Groundwater}

The isotopes of oxygen ${ }^{18} \mathrm{O}$ and hydrogen $\delta^{2} \mathrm{H}$ are a sensitive tracer and widely used in studying the natural water circulation and groundwater movements. Differences in the content of $\delta^{2} \mathrm{H}$ and $\delta{ }^{18} \mathrm{O}$ in groundwater, surface water and rainfall collected at Koforidua were exploited on a similar graph to show the extent of variation in the study area Figure 5. A local meteoric water line (LMWL) obtained by Akiti [1] for the Accra plains (which forms part of the study area) defined by the equation and

Table 1. Statistical summary of the stable isotope data of the study area.

\begin{tabular}{|c|c|c|c|c|c|c|c|c|}
\hline $\begin{array}{c}\text { Water } \\
\text { type }\end{array}$ & $\begin{array}{c}\delta^{2} \mathrm{H} \% \text { o } \\
\text { Min }\end{array}$ & $\begin{array}{c}\delta^{2} \mathrm{H} \% 0 \\
\operatorname{Max}\end{array}$ & $\begin{array}{r}\delta^{2} \mathrm{H} \% \text { o } \\
\text { Mean }\end{array}$ & $\begin{array}{c}\delta^{2} \mathrm{H} \% \\
\mathrm{SD}\end{array}$ & $\begin{array}{c}\delta^{18} \mathrm{O} \% 0 \\
\mathrm{Min}\end{array}$ & $\begin{array}{c}\delta^{18} \mathrm{O} \% \\
\mathrm{Max}\end{array}$ & $\delta^{18} \mathrm{O} \%$ Mean & $\delta^{18} \mathrm{O} \%$ SD \\
\hline Groundwater & -9.40 & -4.70 & -7.35 & 1.62 & -2.72 & -1.62 & -2.28 & 0.37 \\
\hline Surface water & -5.58 & -4.40 & -5.10 & 1.64 & -1.68 & -1.51 & -1.60 & 0.09 \\
\hline Rain & 10.64 & 7.35 & 0.31 & 7.48 & -3.14 & -0.71 & -1.58 & 0.99 \\
\hline
\end{tabular}


Table 2. Results of physico-chemical parameters in the study area.

\begin{tabular}{|c|c|c|c|c|c|}
\hline Town & Code & $\mathrm{pH}$ & Cond $\mu \mathrm{s} / \mathrm{cm}$ & $\mathrm{NO}_{3}-\mathrm{mg} / \mathrm{l}$ & $\mathrm{Cl}-\mathrm{mg} / \mathrm{l}$ \\
\hline CRIG & $\mathrm{CR}$ & 6.38 & 155.20 & 13.97 & 9.70 \\
\hline Maase1 & MS1 & 5.98 & 212.00 & 8.23 & 24.70 \\
\hline Maase2 & MS2 & 6.02 & 261.00 & 7.21 & 29.30 \\
\hline Maase T 1 & MST1 & 6.16 & 317.00 & 29.45 & 43.50 \\
\hline Maase T 2 & MST2 & 6.98 & 287.00 & 12.18 & 19.30 \\
\hline Adowkwanta & ADK & 5.93 & 259.00 & 17.78 & 41.20 \\
\hline Potroase1 & POT1 & 6.37 & 300.00 & 6.82 & 3.40 \\
\hline Potroase 2 & POT2 & 6.66 & 382.00 & 5.55 & 35.50 \\
\hline Asotwene & AST & 6.63 & 535.00 & 4.76 & 83.00 \\
\hline Afabeng Borehole & AF B & 6.70 & 680.00 & 22.34 & 79.00 \\
\hline Afabeng Hand dug well & $\mathrm{AF} \mathrm{H}$ & 7.03 & 722.00 & 28.40 & 124.50 \\
\hline Anyinase & ANY & 5.58 & 314.00 & 9.21 & 59.70 \\
\hline Akooko & $\mathrm{AK}$ & 6.44 & 121.30 & 15.49 & 7.30 \\
\hline Densu Potroase & D POT & 7.48 & 101.90 & 18.89 & 11.00 \\
\hline Densu Akyem Odumase & $\mathrm{D} A K D$ & 7.38 & 115.10 & 35.47 & 10.34 \\
\hline Densu mangoase & DMAN & 7.47 & 141.20 & 39.58 & 9.40 \\
\hline Densu Nsawam & D NS & 7.45 & 191.20 & 44.58 & 14.00 \\
\hline
\end{tabular}

Table 3. Results of stable isotopes in the study area.

\begin{tabular}{|c|c|c|c|c|c|}
\hline Town & Code & Lithology & $\delta^{18} \mathrm{O}$ & $\delta^{2} \mathrm{H}$ & d-excess \\
\hline CRIG & $\mathrm{CR}$ & Granite & -2.44 & -8.00 & 11.52 \\
\hline Maase 1 & MS1 & Granite & -2.72 & -9.40 & 12.36 \\
\hline Maase2 & MS2 & Granite & -2.24 & -7.50 & 10.42 \\
\hline Maase T 1 & MST1 & Granite & -1.62 & -5.30 & 7.66 \\
\hline Maase T 2 & MST2 & Granite & -1.92 & -5.10 & 10.26 \\
\hline Adowkwanta & $\mathrm{ADK}$ & Granite & -2.19 & -7.70 & 9.82 \\
\hline Potroase1 & POT1 & Quartzite & -2.58 & -8.10 & 12.54 \\
\hline Asosotwene & AST & Granite & -2.62 & -8.60 & 12.36 \\
\hline Afabeng Borehole & AF B & Granite & -2.72 & -9.40 & 12.36 \\
\hline Afabeng Hand dug well & $\mathrm{AF} \mathrm{H}$ & Granite & -2.44 & -8.10 & 11.42 \\
\hline Anyinase & ANY & Granodioir & -1.88 & -4.70 & 10.34 \\
\hline Akooko & $\mathrm{AK}$ & Granite & -1.77 & -5.60 & 8.56 \\
\hline Potroase2 & РOT2 & Quatrtzite & -2.45 & -8.10 & 11.50 \\
\hline Densu Potroase & D POT & Quartzite & -1.54 & -4.90 & 7.42 \\
\hline Densu Akyem Odumase & D AKD & Granite & -1.68 & -5.58 & 7.86 \\
\hline Densu mangoase & D MAN & Granite & -1.51 & -4.40 & 7.68 \\
\hline Densu Nsawam & D NS & Granite & -1.66 & -5.50 & 7.78 \\
\hline Rain water 17 & $\mathrm{RN}$ & Rain water & -3.14 & -10.64 & 14.44 \\
\hline Rain water21 & $\mathrm{RN}$ & Rain water & -1.28 & 3.26 & 13.48 \\
\hline Rain water22 & $\mathrm{RN}$ & Rain water & -0.71 & 7.35 & 13.01 \\
\hline Rain water 23 & $\mathrm{RN}$ & Rain water & -1.96 & -3.96 & 11.69 \\
\hline Rain water 24 & $\mathrm{RN}$ & Rain water & -0.85 & 5.54 & 12.31 \\
\hline
\end{tabular}




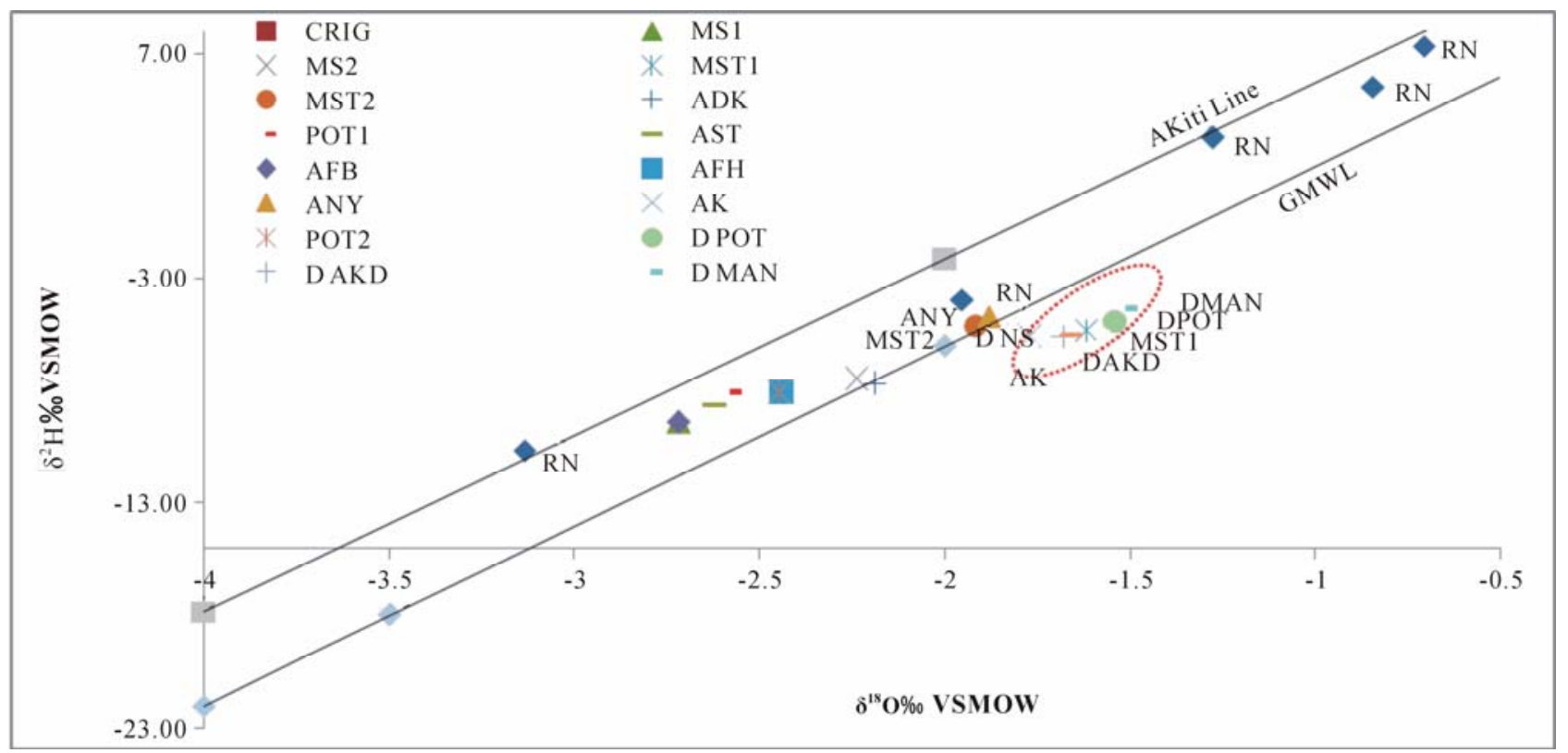

Figure 5. A plot of $\delta^{18} \mathrm{O}$ against $\delta{ }^{2} \mathrm{H}$ for ground and surfaces water.

$$
\partial^{2} \mathrm{H}=7.86 \partial^{18} \mathrm{O}+13.61
$$

the Global meteoric water line [2], defined by the equation

$$
\partial^{2} \mathrm{H}=8 \partial^{18} \mathrm{O}+10
$$

were also inserted in the graph.

The stable isotope composition relative to Global Meteoric Water Line (GMWL) reveals important information on the groundwater recharge patterns, relationship between ground and surface water. As evident from Figure 5, most groundwater samples plot in between the GMWL and LMWL with few samples falling on the lines. This suggests a meteoric origin for the groundwater. The groundwater in the study area appears to group in a narrow range, signifying a well-mixed system with relatively constant isotopic composition. A few (15\%) of the groundwater samples plot slightly away from the meteoric water line showing an evidence of small isotopic enrichment by evaporation on the surface or in the unsaturated zone before recharge. This shows that, generally, the meteoric water recharging the groundwater system in the area is homogeneous with evaporation playing an insignificant role on the infiltrating water. Similar observations were made in the southern portion of the basin [22]. All the surface waters plot relatively below the global meteoric water line indicating a degree of isotopic enrichment. This observation can be attributed partly to the open flow of the river and to some extent the isotopic enrichment could be reflecting the integration of isotopic composition of the Densu river tributaries. The narrow range in the stable isotopic composi- tion of the surface water shows a homogeneous and well mixed system between the Densu River and its tributaries.

It is interesting to note that two of the groundwater samples exhibit similar isotopic composing to that that of the surface water (River Densu), this suggest a possible hydraulic connection between the aquifers and the river water, some degree of fractionation both on land surface and in the unsaturated zone and most probably mixing mechanisms by anthropogenic activities such as irrigation, which might result in the groundwater being recharge by enriched waters.

\subsection{Origin of Dissolve Ions in the Groundwater}

Conventionally, the sources of dissolve ions in water bodies could be deduce from the variation of the characteristic solute-concentration ratios such as $\mathrm{Na}^{+} / \mathrm{Cl}^{-}$, $\mathrm{Ca}^{2+} / \mathrm{Mg}^{2+}, \mathrm{SO}_{4}{ }^{2-} / \mathrm{Cl}^{-}, \mathrm{Br}^{-} / \mathrm{Cl}^{-}$etc. however, in certain situations, water chemistry may undergo secondary changes such as ion exchange, Oxidation and reduction, precipitation, evaporation etc which make it very difficult to use ion-ratio approach to identify the sources of these ions.

Stable isotopes of water (deuterium and oxygen-18) being relatively invariance over time, are therefore, well suited to study the complexities of groundwater hydrology in an area. Groundwater undergoing evaporation will have a positive correlation between $\delta^{18} \mathrm{O}$ and Conductivity. In the diagram of $\delta^{18} \mathrm{O}$ vrs Conductivity Figure 6, it was observed that, a negative correlation was obtained with $\mathrm{R}^{2}=0.062$, furthermore in most samples an increase 


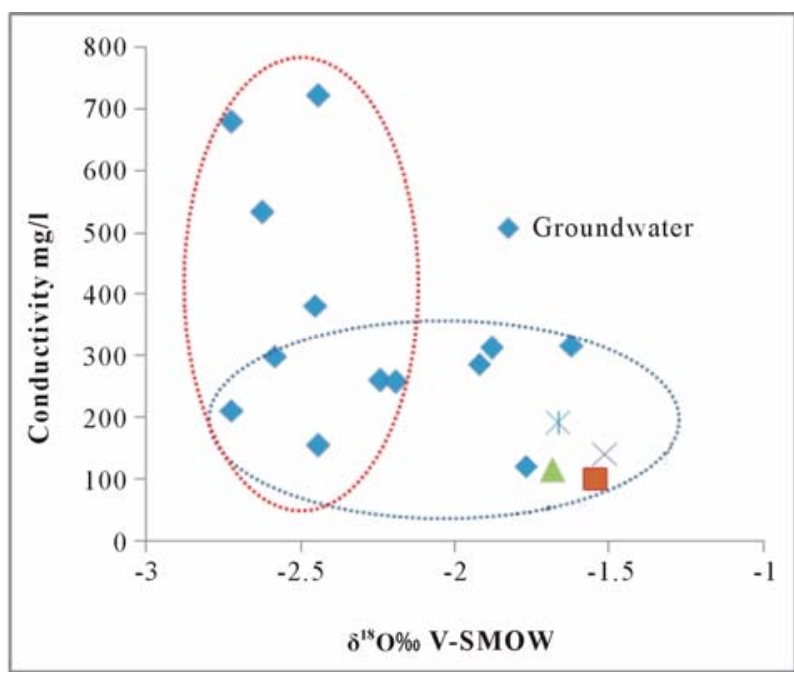

Figure 6. A plot of oxygen-18 against conductivity.

in electrical conductivity(EC) values takes place without much changes in isotopic composition, which may be due to mineralization. Few of the groundwater and all the surface waters shows an enrichment of the heavier isotopes without a simultaneous increase in EC, this lead to confirm that some of the groundwater appear to be recharge by evaporated water (isotopically enriched) water on the surface or in the unsaturated zone or by the river water.

At any point or area in the saturated aquifer, the water recharging through the unsaturated zone and the lateral flow from surrounding areas mainly control the nitrate contents in the groundwater. It has been reported that the groundwater recharge to the fractured aquifers in the crystalline rocks in some part of Ghana takes place by direct and rapid infiltration to escape evaporation [1].

It was also observed from Table 3 that most of the groundwaters in the area have $\delta^{18} \mathrm{O}$ values within the reported annual average rainfall $\delta^{18} \mathrm{O}$ range of -7.4 to $+1.3 \%$ [14]. This suggests that the local effect plays a significant role in changing the $\delta$ value of groundwater. Therefore, depending on the recharge/infiltration characteristics and the period of stay of water on the land surface (and thereby subjected to evaporation) at different locations, some kinds of correlation are expected between $\delta^{18} \mathrm{O}$ and $\mathrm{NO}_{3}{ }^{-}$contents of groundwater. It is interesting to note from Figure 7 that barring few points, generally, low nitrate groundwater are associated with high $\delta^{18} \mathrm{O}$ water. This shows an indication of anaerobic conditions at deeper levels in the soil profile [23], the basin is currently undergoing fast urbanization and changes in land use, this had lead to the compaction of the soil and reduced thickness of the aerated zone [23].

Similar observations have also been reported for the soil profiles in the study area [24]. Few high nitrate

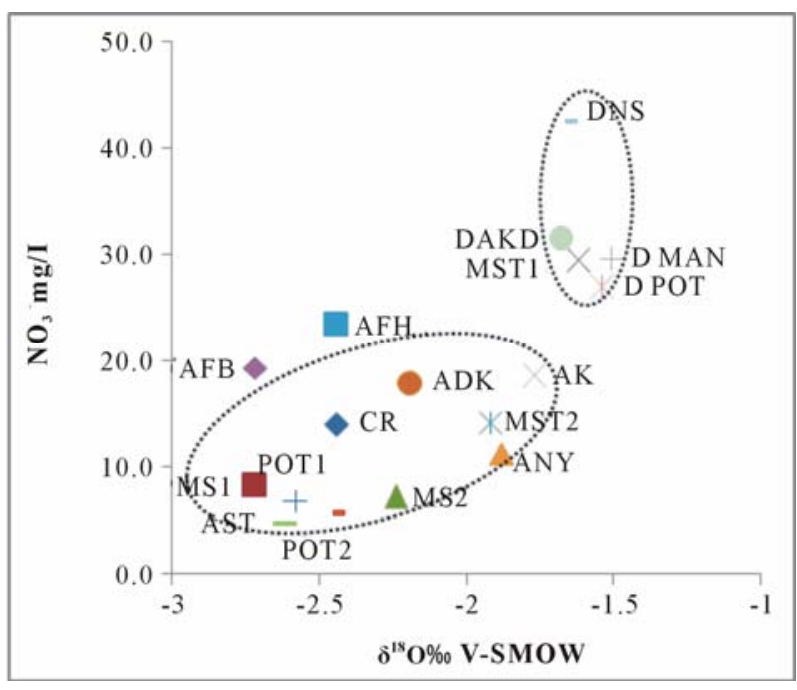

Figure 7. A plot of oxygen-18 vrs nitrate.

groundwater were also found to be associated with high $\delta^{18} \mathrm{O}$ value; this shows that some of the wells are recharge by significant quantities of evaporated $\left({ }^{18} \mathrm{O}\right.$ enriched) rainwater infiltrating along with nitrate salts from the soil to the groundwater system. The data points deviate from the main trends depending on the degree of evaporation/recharge $[23,25]$. This further suggests that there is an imbalance between plant uptake and nitrate produced naturally or from fertilizers in the soil.

Stable isotopes can also provide an independent variable which can assist in identifying the mechanism of Salinization. Salinization arising from leaching of salts is not accompanied by changes in stable isotope composition of the leaching water while Salinization as a result of evaporation is accompanied by increase in stable isotope composition (enrichment). The mechanism of Salinization for surface and groundwater of the Densu river basin has been illustrated in Figure 8. In these diagrams, it can be observed that, there are two main kinds of waters; the first group is waters in which leaching of salts lead to salinization, so there were no significant differences between their stable isotope compositions.

The second groups are those affected by both evaporation and leaching of salts together, all the surface waters and some few groundwaters belong to this group. This further supports the point that, dissolutions of minerals from the geology is the main controlling factor of the groundwater chemistry in the study area.

\subsection{D-Excess}

The deuterium excess (d-excess) reflects the conditions that lead to kinetic isotope fractionation between water and vapour during primary evaporation in the oceans [5].

This number also shows the extent of deviation of a 


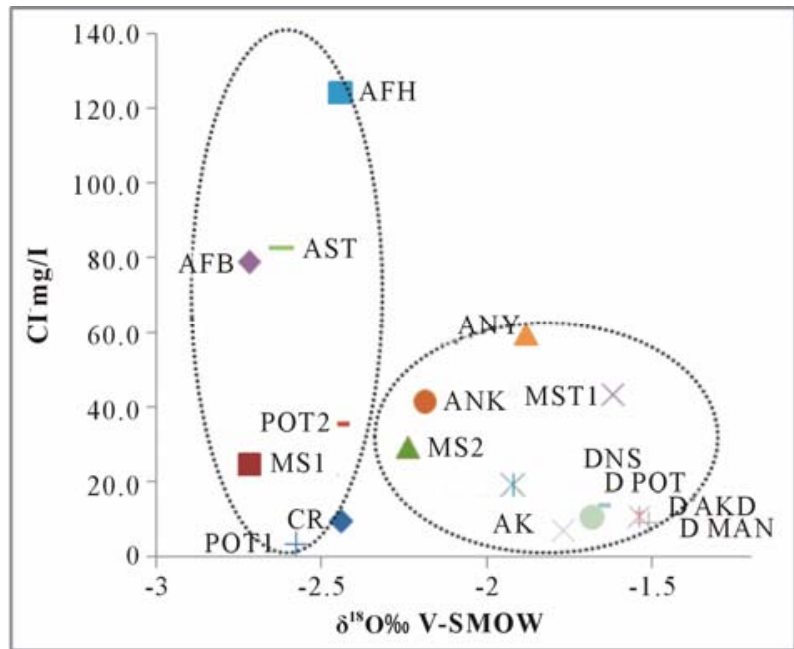

Figure 8. A plot of $\delta^{18} \mathrm{O}$ vrs chloride in $\mathrm{mg} / \mathrm{l}$.

given sample from the meteoric water line. The calculated deuterium excess of the rainfall was found to be very narrow, ranging from 11.69 to $14.44 \%$ confirming a common moisture source for the rainfalls. The groundwater d-excess values ranges from 7.66 to $12.54 \%$, while that of the surface water ranges between 7.42 to $7.86 \%$. As the $\delta^{18} \mathrm{O}$ increases (more enriched) the deuteriumexcess in all the samples decreases gradually Figure 9. It is also noticed that the groundwater samples plot in between the rainfall and the surface water.

This observation can be partly attributed to the dilution of the groundwater with the rainfall which could increase the d-excess [26]. Furthermore, the tendency towards the rainfall may imply a modern recharge to the groundwater systems.

\section{Conclusions}

This study has shown that, the groundwater in the northern part of the Densu River basin exhibit a relatively constant isotopic composition and scattered along the LMWL and GMWL. This shows that, the groundwater in the study area are mainly meteoric which undergone slight primary evaporation. The narrow range in isotopic composition is an evidence of a well mixed system. Very few of the groundwater shows an evidence of isotopic enrichment. This may be due to evaporation on the surface or in the unsaturated zone before recharge, contribution from anthropogenic sources such as irrigation or a possible hydraulic connection between the river and the groundwater. All the surface water deviates from the meteoric water line signifying isotopic enrichment due to the open flow of the river, hence subject to evaporation.

Though evaporation of water and concentration of minerals to some extent may contribute to the presence

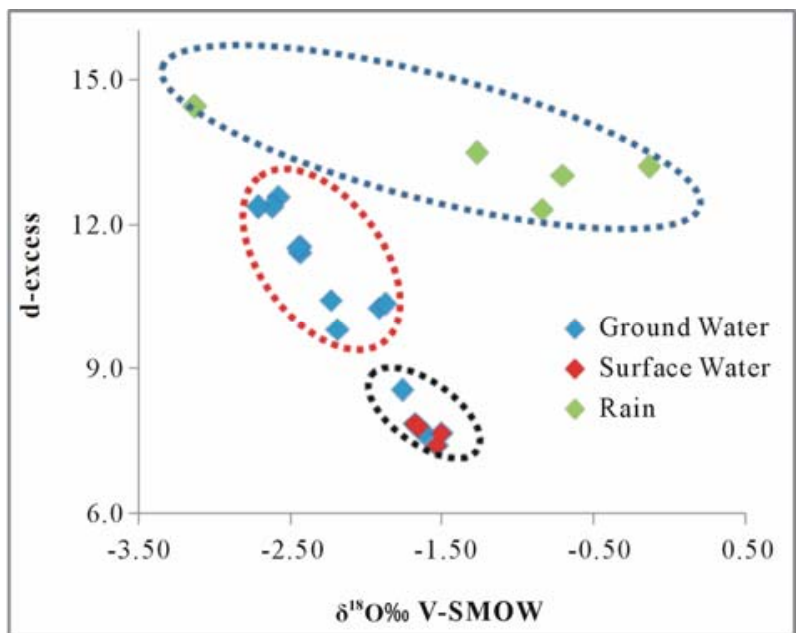

Figure 9. A plot of $\delta^{18} \mathrm{O}$ vrs d-excess.

of ions and salinization; water-rock interactions and mineral dissolution are the major factors controlling the origin of dissolve ions and salinization in the study area.

Finally, the narrow d-excess in the rainfall shows that, the moistures forming the rainfall are from a common origin. The evidence of mixing and dilution of groundwater with rainfall, which might indicate modern recharge:, is seen in increase in d-excess in the groundwater towards the rainfall values. The decreasing in the deuterium excess of collected groundwater samples with increasing $\delta^{18} \mathrm{O}$ indicates that, the current groundwater mixes with different rainfall events with different average isotopic values undergoing different degree of evaporation before recharge.

\section{Acknowledgements}

The authors wish to thank NNRI of the Ghana Atomic Energy Commission, the staff of chemistry department and for their support. We also wish to thank the Co-ordinator of the Graduate school of nuclear and Allied sciences, Prof. J. H. Amuesi for providing transport. Finally, we wish to thank the Ghana Meteorological Agency for providing the meteorological data.

\section{References}

[1] T. T. Akiti, "Environmental Isotope Study of Groundwater in Crystalline Rocks of the Accra Plains," 4th Working Meeting Isotopes in Nature, Proceedings of an advisory group meeting, IAEA, Vienna, 1986.

[2] B. K. Das, Y. P. Kakar, H. Moser and W. Stichler, "Deuterium and Oxygen-18 Studies in Groundwater of the Delhi Area, India," Journal of Hydrology, 1998, pp 133146.

[3] G. Faure, "Principles of Isotope Geology," John Wiley \& 
Sons, New York, 1986.

[4] H. Craig, "Isotopic Variation in Meteoric Water," Science, Vol. 133, No. 3465, 1961, pp. 1702-1703.

[5] W. Dansgaard, "Stable Isotopes in Precipitation," Tellus, Vol. 16, No. 4, 1964, pp. 436-468.

[6] J. Jouzel and L. Merlivat, "Deuterium and Oxygen-18 in Precipitation: Modeling of the Isotope Effects during Snow Formation," Journal of Geophysics Research, Vol. 89, No. D7, 1984, pp. 11749-11757.

[7] J. R. Gat, C. Bowser and Kendall, "The Contribution of Evaporation from the Great Lakes to the Continental Atmosphere: Estimate Based on Stable Isotope Data," Geophysics Research and Letters, Vol. 21, No. 7, 1994, pp. 557-560.

[8] A. Kondo and J. Shimata, "The Origin of Precipitation in Eastern Asia by Deuterium Excess," Journal of Society of Hydrology and Water Resources, Vol. 10, No. 6, 1997, pp. 627-629.

[9] J. C. Fontes, "Environmental Isotopes in Groundwater Hydrology in Handbook of Environmental Isotopes Geochemistry," Fritz and Fontes, Vol. 1. Elsevier, 1980, pp. 75-140.

[10] IAEA, "Guidebook on Nuclear Techniques in Hydrology," Edition Technical Report Series No. 91, Vienna, 1983.

[11] K. B. Peligba-Ba, "Analysis of Stable Isotope Content of Surace and Underground Water in Two Main Geological Formation in the Northern Region of Ghana," West Journal of Applied Ecology, Vol. 15, No. 1, 2009.

[12] B. K. Kortatsi and N. K. Sekpey, "Chemical and Isotopic Techniques for the Origin of Groundwater in the Crystalline Basement Complex of the Upper Region of Ghana," Regional Trend in Geology in African Geology, Proceedings of the 9th international Geological Conference, Accra, November 1992.

[13] K. B. Banoeng-Yakubu, “Application of Remote Sensing and Geographical Information System to Hydrological Studies in the Upper West Region of Ghana," 2000.

[14] S. Y. Acheampong and J. W. Hess, "Origin of the Shallow Groundwater System in the Southern Voltaian Sedimentary Basin, Ghana," Hydrogeology Journal, Vol. 6,
2000, pp. 527-537.

[15] J. R. Fianko, O. Osae, D. Adomako and D. G. Achel, "Relationship between Land Use and Groundwater Quality in Six Districts in the Eastern Region of Ghana," 2008.

[16] K. B. Banoeng-Yakubu, "Occurrence of Groundwater in Basement Complex Rocks of the Upper Region of Ghana," M.Sc. Thesis, Obefemi-Awolowol University, 1989.

[17] S. Y. Ganyaglo, "Hydrochemical and Isotopic Characterization of Groundwater in Some Rock Types in the Eastern Region of Ghana," Unpublish Mphil Thesis, 2009

[18] S. N. Davis and L. J. Turk, "Optimum Depth of Wells in Crystalline Rocks," Groundwater, Vol. 2, No. 2, 1964, pp. 6-11.

[19] D. K. Buckley, "Report on Advisory to Wateraid Projects in Ghana," Unpublished Report, British Geological Survey, Hydrogeology Research Group, Willingford, 1986.

[20] P. Seismos, "The 30 Well Project," Internal Report, Catholic Diocese of Accra, 1984.

[21] Water Research Institute (WRI), "Borehole Yield Map of Ghana," Unpublished Technical Report, Accra, 1994.

[22] Goucey, et al., "Application of Isotope Techniques for the Assessment of Groundwater Resources: Densu River Basin Report," 2008.

[23] P. S. Datta, D. L. Deb and S. K. Tyagi, "Assessment of Groundwater Contamination from Fertilizers in the Delhi Area Based on $818 \mathrm{O}, \mathrm{NO}_{3}{ }^{-}$and $\mathrm{KC}$ Composition," Journal of Contaminant Hydrology, Vol. 27, No. 3-4, 1997, pp. 249-262.

[24] K. P. Bam, "Major and Trace Elements in Soil Profile of the Unsaturated Zone of the Densu River Basin, Ghana," Unpublish Mphil Thesis, 2009.

[25] P. S. Datta, D. L. Deb and S. K. Tyagi, "Stable Isotope $(\delta 180)$ Investigations on the Processes Controlling Fluoride Contamination of Groundwater," Journal of Contaminant Hydrology, Vol. 24, No. 1, 1996. pp. 85-96.

[26] F. Yuan and S. Miyamoto, "Characteristics of Oxygen-18 and Deuterium Composition in Waters from Pecos River in American Southwest," Chemical Geology, Vol. 255, No. 3-4, 2008, pp. 220-230. 